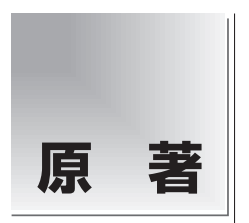

論文受付

2012 年 4 月 2 日

論文受理

2013 年 4 月 23 日

Code No. 852

\section{線量分布解析に打ける \\ ラジオクロミックフィルムドジメトリーの \\ 正確性の向上に関する取り組み \\ 一フラットベッドスキャナの影響の補正法と \\ 色成分を利用した補正法の組み合わせ一}

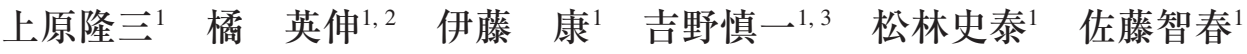 \\ ${ }^{1}$ がん研究会有明病院放射線治療部 \\ 2 現 テキサス大学サウスウェスタンメディカルセンター放射線腫瘍部医学物理工学部門 \\ ${ }^{3}$ 現 神奈川県立がんセンター放射線第二科
}

\section{緒 言}

強度変調放射線治療(intensity modulated radiation therapy: IMRT)の患者プランの quality assurance(QA)を 代表として, 線量分布の解析は, 放射線治療の物理特
性を評価するにあたって多く用いられている。線量分布 の解析は, IMRTのガイドラインに準じて電離箱線量計 を基準とする絶対線量測定と，フィルムを基準とする相 対線量分布解析に分けられる。電離箱線量計を基準と

\title{
A Practical Procedure to Improve the Accuracy of Radiochromic Film Dosimetry: A Integration with a Correction Method of Uniformity Correction and a Red/Blue Correction Method
}

\author{
Ryuzo Uehara, ${ }^{1 *}$ Hidenobu Tachibana, ${ }^{1,2}$ Yasushi Ito, ${ }^{1}$ Shinichi Yoshino, ${ }^{1,3}$ \\ Fumiyasu Matsubayashi, ${ }^{1}$ and Tomoharu Sato ${ }^{1}$ \\ ${ }^{1}$ Department of Radiation Oncology, The Cancer Institute Hospital of JFCR \\ ${ }^{2}$ Current address: Department of Radiation Oncology, University of Texas Southwestern Medical Center \\ ${ }^{3}$ Current address: Department of Radiation Oncology, Kanagawa Cancer Center
}

Received April 2, 2012; Revision accepted April 23, 2013

Code No. 852

\section{Summary}

It has been reported that the light scattering could worsen the accuracy of dose distribution measurement using a radiochromic film. The purpose of this study was to investigate the accuracy of two different films, EDR2 and EBT2, as film dosimetry tools. The effectiveness of a correction method for the non-uniformity caused from EBT2 film and the light scattering was also evaluated. In addition the efficacy of this correction method integrated with the red/blue correction method was assessed. EDR2 and EBT2 films were read using a flatbed charge-coupled device scanner (EPSON 10000G). Dose differences on the axis perpendicular to the scanner lamp movement axis were within $1 \%$ with EDR2, but exceeded 3\% (Maximum: $+8 \%$ ) with EBT2. The non-uniformity correction method, after a single film exposure, was applied to the readout of the films. A corrected dose distribution data was subsequently created. The correction method showed more than $10 \%$-better pass ratios in dose difference evaluation than when the correction method was not applied. The $\mathrm{red} / \mathrm{blue}$ correction method resulted in 5\%-improvement compared with the standard procedure that employed red color only. The correction method with EBT2 proved to be able to rapidly correct non-uniformity, and has potential for routine clinical IMRT dose verification if the accuracy of EBT2 is required to be similar to that of EDR2. The use of red/blue correction method may improve the accuracy, but we recommend we should use the red/blue correction method carefully and understand the characteristics of EBT2 for red color only and the $\mathrm{red} / \mathrm{blue}$ correction method.

Key words: film dosimetry, radiochromic film, intensity modulated radiation therapy quality assurance (IMRT QA), flatbed scanner, red/blue correction

*Proceeding author 
する絶対線量測定は, 急峻な線量勾配を有する線量分 布を測定する際，その線量計の設置の精度によって測 定結果に大きく影響を及ぼす可能性がある。また，相 対線量分布解析は, フィルムのほかに線量測定におけ る空間分解能 $0.5 \mathrm{~mm}$ から $10.0 \mathrm{~mm}$ を有した二次元多 列測定器 ${ }^{1 \sim 4)}$ や擬似三次元多列測定器 ${ }^{5 \sim 8)}$ がある. これ らは線量測定と同時に解析が可能であり, 効率的な IMRTの患者プラン検証に用いられ，また治療計画装 置のコミッショニングなどをはじめとして多く利用され 始めている。 しかし，照射野径が $4 \mathrm{~cm}$ 以下の小照射野 を利用した stereotactic radiosurgery(SRS)や stereotactic body radiotherapy (SBRT)，さらに頭頸部のような大照 射野で急峻に線量分布が変化する IMRT や volumetric modulated arc radiation therapy(VMAT)には上記の多列測 定器の空間分解能では充分に評価できない場合があり, また，測定できる断面の自由度は測定器の設計によって 制限されている。したがって，いまだフィルムを用いた 線量分布の解析が多く行われており，必要性も高い。

現在，線量分布解析に利用できるフィルムはラジオ グラフィックフィルムとラジオクロミックフィルムの 2 種類である。 ラジオグラフィックフィルムの代表的な IMRT 検証用のフイルムとして Kodak 製 EDR2(EDR2) があげられる．線量分布解析を行うにあたって測定精 度を向上させる取り組みに関し，例えば，測定精度が， フィルムの型番を統一することで $5 \%$ 以内に，潜像成長 の時間を 1.5 時間以上にすることによって $1 \%$ 以内にす ることができるなどの報告がある ${ }^{9111}$ ，したがって，そ の報告を考慮したプロトコールにて照射から現像，解 析を行うと絶対線量測定として 1 3\% 程度の精度での 測定が可能である ${ }^{9111}$. EDR2 は線量分布の評価におい て非常に有用ではあるが，暗室での取り扱いによる煩 雑さや自動現像機の管理が必要であり, 現在, 病院の フィルムレス化が進んでいることもあることから， EDR2 の利用に対して困難さが生じる場合がある。 それ に対して，ISP 製 $\mathrm{EBT}^{12)}(\mathrm{EBT}) や$ ISP 製 EBT2 ${ }^{13)}(\mathrm{EBT} 2)$ を代表とするラジオクロミックフィルムは，明室での取 り扱いが可能, 自動現像機が不要, 広いエネルギー範 囲の光子線拧よび粒子線に対応可能 14 16)，そして水中 下での利用が可能といった EDR2 にはない特長を有し ている17)。また，素材が水組織等価物質に近い点から 低エネルギー $X$ 線に対する感度は EDR2 に比べ小さ い，そして，EDR2 と同様にフィルム特有の高い空間分 解能を有していることから, IMRTのような複雑な線量 分布の評価において適しており，また，光子線治療に おいて SRS や SBRT, さらにIMRT や VMAT ${ }^{18)}$ が盛ん に行われるとも予測できることから，今後フィルム測定
法の必要性はさらに高まると考えられる.

しかし，EBTやEBT2の利用において，同一フィル ムに打ける感光物質の粒子ムラやロットごとの感光物質 の塗布ムラなどがフラットベッドスキャナの読み取り位 置の違いによる測定值の誤差要因になるという報告が ある19 21)。また, 二次元検出器として EBTは, EDR2 に比べ IMRT のプラン検証の検出器として精度が低い という報告がある22,23)。したがって, EBT, EBT2の利 用は, EDR2 が達成する検出器としての空間分解能や解 像度といった精度に対し, 感光物質の塗布ムラや雑音 などの問題から精度は低くなってしまうと考えられる。

現在，フィルムを用いた線量分布の解析において, フラットベッドスキャナの利用が一般的であるが，フ ラットベッドスキャナの利用と EBT, EBT2 の組み合わ せによる測定精度は, フィルム自体の素材や構造が影 響し悪化するという報告がある21, 24)，その影響を除去す る方法について, back ground correction 法が報告され て扔り ${ }^{24)}$ ，その方法は，毎回の測定時に線量分布測定 のためのフィルムとは別に校正用のフィルムを作成する 必要があり，効率性にそしいことが実際の臨床に招け る利用の障害になると考えられる。.Menegottiらは, EBT およびEPSON V750 と 1680Pro というフラット ベッドスキャナを利用した際の線量分布測定に対して, スキャナ光源由来の不均一性の影響に補正を行うこと で，線量分布測定精度が向上するという報告をした ${ }^{211}$. この方法は，補正係数算出用に作成したフィルムを走 查し，その線量プロファイルから二次方程式を用いた関 数による補正係数を求め, 線量分布測定に利用する フィルムに対して，その補正係数を用いて補正を行うこ とで測定精度を向上させる。 これは，同一ロットのフィ ルムに対し一旦補正係数を求めればフィルムロットが変 わるまで使用し続けることが可能であり，実際の臨床に おける QA の効率性にとって有効であると考えられる. また，利用するフラットベッドスキャナの違いによって スキャナ光源からの発光量が変化すると考えられること から，その補正係数も変化すると考えられる，スキャナ の種類は多数あり,ささざまな施設で異なるスキャナが 導入され利用されていることが考えられるため，その手 法を採用して臨床に用いるにあたり汎用性に優れると考 えられる。

また，ラジオクロミックフィルムを利用した際の測定 精度の向上を目的とした方法として, red/blue correction 法が提案されている。しかしながら, red/blue correction 法は測定精度の向上 ${ }^{25,26)}$ および低下 ${ }^{27,28)}$ の両者に関す る報告があることから，実際の利用において測定精度 の向上が可能か不明瞭である，さらにこのスキャナ光源 
由来の補正法と red/blue correction 法の組み合わせに関 する線量分布解析への報告がない.

以上から, 本研究では, まずEDR2 とEBT2を用 い, フラットベッドスキャナによる両者への光学濃度の 影響を明らかにし，その影響が線量分布測定精度に影 響するかを検証する。また，過去の報告において Menegotti らの補正法はEBT2 について言及されておら ず，また，フラットベッドスキャナによる不均一性の影 響を補正する方法と red/blue correction 法との組み合わ せに関し, 線量分布解析への影響が報告されていな い. そこで当院の測定システム環境において, 不均一 性の補正係数を求め, EBT2 に対しても有効であるか検 証を行い, フラットベッドスキャナの影響の補正と赤色 の要素(赤色成分)および red/blue correction 法とで作成 した要素(赤色/青色成分)を用いた際の解析との組み 合わせによる影響を検証した。

\section{1. 方 法}

本研究では EDR2, EBT2(Lot3：A052810-02AAA)の 2 種類のフィルムを使用し, フラットベッドスキャナに は EPSON-Seiko 製 $10000 \mathrm{G}$ を使用した。治療照射装置 は Varian Clinac 21EX, 計画装置は Eclipse Version 8.1, 線量計算アルゴリズムは anisotropic analytical algorism （AAA）を使用した。 不均一性の補正式は, 濃度 - 線量 曲線を利用して作成するため, 絶対線量測定には Farmer 形空気電離箱線量計 TN30013 \#1938, 電位計 RAMTEC 1000 plus \#305を使用した. 線量分布評価に 打ける基準値として, 二次元多列空気電離箱線量計 IBA Dosimetry 製 I'mRT MatriXX を使用した。また, 水等価ファントムとして, 株式会社京都科学製 Tough Water ファントムを使用した，フィルム解析ソフトウェア は Triangle Products 製 Simple IMRT Analysis GafChromic Package(version 1.3.0.0)を使用した。不均一性の補正係 数は, フィルムの線量プロファイルから関数を求める必 要があるため, 同ソフトウェアを用いて線量プロファイ ルを取得した。また, I'mRT MatriXX を基準值として EDR2 と EBT2 を比較するためにプロファイルや線量差 の二次元マップ, また, 線量差の許容值を $3 \%$ と, そ れを達成できた比率(pass ratio)を, 同ソフトウェアを用 いて求めた，この際，線量域の $30 \%$ 以下は評価の対象 から除外した。

EBT2 のフラットベッドスキャナによる画像の取得 は, post exposure density growth といった自己成長によ るフィルム濃度の変化を考慮して, 照射後 24 時間後に 行った．また，EBT2のフィルムの読み込みは，当院の プロトコールに従い行った。すなわち, フィルムをス
キャナ光源の走査方向に対して垂直方向にフィルムの 長軸が位置するように，またフィルムの表を光源側に向 けて行った。 フィルム読み取り用アプリケーションは EPSON scan を用い，モードは Professional mode(画像 調整, 色調調整オフ), 分解能は 72 dot per inch(dpi), 42 bit三原色成分(red green blue: RGB)，保存形式は tagged image file format(TIFF)で行った。 スキャンを開 始する前に, スキャナ光源のエージングのためウォーミ ングアップとして空スキャンを 3 回行った。 フィルムを 読み込む際の設置位置は，スキャナ走査面に扔ける光 源強度のばらつきによる影響を排除するためガイドを使 用し，長軸がスキャナ光源の中央，短軸がスキャナ光 源の走查方向に対して水平方向の移動範囲の中央にく るように，スキャナ走査面に対して毎回同一位置に設置 した。

\section{1-1 EDR2 と EBT2 におけるフラットベッドスキャ} ナの光学濃度に対する影響

EBT2 は，スキャナで読み込む際にフラットベッドス キャナの性質によって, スキャナ光源の走査方向に対し て水平方向(走查水平方向)上り垂直方向(走査垂直方 向)の方が顕著な不均一性を示すことが報告されてい $3^{211}$ ，その原因は，フィルム内の感光物質の粒子によっ てスキャナ光源からの光が拡散され，その影響が蛍光 ランプの長軸上に顕著に現れるためである。そのため 均一に照射されたフィルムであったとしても, 辺縁と比 較して, 中央の方が拡散された光が集まり, 光学濃度 が低下(黒から白へ移行)してしまう。したがって，本研 究ではEDR2 とEBT2 を用い, その影響を比較した。

検証方法は, I'mRT MatriXX および EDR2, EBT2 に対して同一照射条件下[深さ：10 cm(source surface distance(SSD): $90 \mathrm{~cm}$ ), 照射野サイズ : $20 \times 20 \mathrm{~cm}^{2}$, 使用 エネルギー: $6 \mathrm{MV} \mathrm{X}$ 線, 処方線量 : $2.5 \mathrm{~Gy}$ ]で照射を 行った，そして, EDR2 とEBT2の走査水平方向, 走査 垂直方向のプロファイルを取得し, I'mRT MatriXX で取 得した測定值と EDR2, EBT2 のプロファイルとの比較 を行った。また, I'mRT MatriXX の測定值と, EDR2 と EBT2 の測定值からそれぞれの線量差を求め, EDR2 と EBT2 の線量差に対して $\mathrm{t}$ 検定を行い, 有意差を求めた。

また, 光学濃度 (optical density: $O D$ ) は下記の式で算 出した.

$O D=-\log _{10}\left(\frac{P V}{65535}\right)$

Pixel value $(P V)$ は, フラットベッドスキャナで読み 取ったフィルム画像のピクセル值である. 


\section{1-2 EBT2 の走査垂直方向における不均一性を補 正する方法}

前述したように, EBT2 は走査垂直方向に不均一性を 示し，これは線量分布解析に大きく影響することから，

この影響を補正することができれば，EBT2の利用に関 して測定精度の向上が期待できる，そこで, Menegotti らの報告 ${ }^{21)}$ 参考にし，当院での IMRT プラン検証な どの線量分布検証において実際に利用できるような不 均一性の補正法を作成した

(1)補正用フィルムの作成

不均一性の補正に用いるフィルムを作成した。照射 条件は, フィルムをファントムの深さ $5 \mathrm{~cm}$ に設置し た．このとき，走査垂直方向での光学濃度の均一性を 高めるため, SSD を最大限に離した SSD: $140 \mathrm{~cm}$ に設 定して，できるかぎり平坦なビームを照射するようにし た。使用エネルギーは $6 \mathrm{MV} \mathrm{X}$ 線，処方線量は 0.34 ,

$0.63,0.94,1.26,1.55,1.90,2.22,2.51,2.85,3.11 \mathrm{~Gy}$ の計 10 通りを五つに分け，2枚のフィルムに照射を 行った(Fig. 1). 光学濃度の均一性を確かめるため, 同 じ測定環境に扔いて, フィルムの代わりにI'mRT MatriXX を利用して線量プロファイルを求め, そこから 平坦度を求めた，照射野は各 $2.4 \times 30 \mathrm{~cm}^{2}$ (フィルムの深 さで各 $3.48 \times 43.5 \mathrm{~cm}^{2}$ )で，フィルムを移動させずに照射 野を変更させて照射を行った，各処方線量は Farmer 型 線量計にて照射野中心の線量を測定し, 確認を行っ た。また，この補正用フィルムを利用して補正式を求め るために必要な走査垂直方向の光学濃度のプロファイ ルを求めた。それぞれのプロファイルは各処方線量に 対応した照射野の中央部分から測定した.

(2)走査垂直方向に打ける不均一性の補正式

作成した補正用フィルムの光学濃度を利用して走査 垂直方向に打ける不均一性の補正を行う。未補正画像 と補正画像の関係は以下の通りである.

$\operatorname{Image}_{\text {corrected }}(i, j, O D)=\frac{\operatorname{Image}_{\text {uncorrected }}(i, j, O D)}{\operatorname{FitCF}(i, O D)}$

補正係数 $F i t C F(i, O D)$ は, 走查垂直方向に扔ける不 均一性の補正係数である。 $i$ は走查垂直方向の座標, $j$ は走查水平方向の座標である. 補正係数 Fit $C F(i, O D)$ は, 走査垂直方向に扮けるピクセル位置に依存した空 間補正プロファイルと光学濃度から算出される.

まず補正用フィルムから走査垂直方向の光学濃度の プロファイルから近似多項式 Fit $O D(i, O D)$ を作成する。

$F i t O D(i, O D)=a(O D) x^{3}(i)+b(O D) x^{2}(i)+c(O D) x(i)+d$

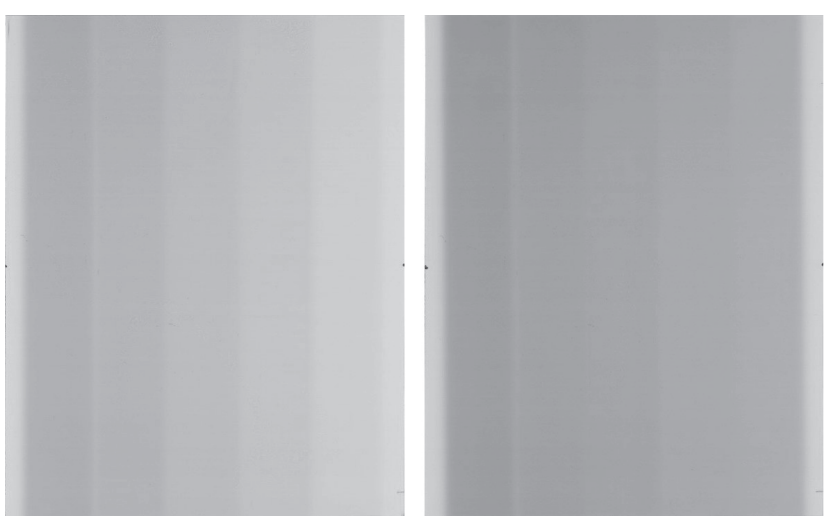

Fig. 1 Two films used for correction: ten stripes with different prescribed doses $(0.34,0.63$, $0.94,1.26$, and $1.55 \mathrm{~Gy}$; and 1.90, 2.22, 2.51, 2.85 , and $3.11 \mathrm{~Gy}$ ).

The field size for each stripe was $2.4 \times 30 \mathrm{~cm}^{2}$.

係数 $a, b, c, d$ は各次数の係数で, $x(i)$ は走査垂直 方向のピクセル位置である. 式(3)の次数は, 二次式お よび三次式を提案し，相関係数の值とプロファイルの形 状から，三次式を選択した。つぎに，前述で作成した 式(2) から不均一性の補正係数である近似多項式 $F i t C F(i, O D)$ を作成する。不均一性の補正係数は，又 キャナ光源の中央に位置するフィルムの光学濃度に対 する走查垂直方向における光学濃度の比であるため, 走査垂直方向の光学濃度のプロファイルの最小值で正 規化を行う必要がある. しかし, 走查垂直方向の光学 濃度のプロファイルは, 感光物質の塗布ムラなどの影響 によって雑音を多く含み, raw デー夕を用いて最小值で 正規化を行った場合, 最小值がフィルムの雑音の数值 となり, 近似多項式の極小值が1にならない. そこで, 杂隹音の影響を除去するため, 前述で作成した式(3)を用 い，その多項式の最小值で正規化を行うことで，極小 值が 1 になる光学濃度 $F i t O D(i, O D)$ のプロファイル Norm $(i, O D)$ を求める.

$\operatorname{Norm}(i, O D)=\frac{F i t O D(i, O D)}{\operatorname{Min}[\operatorname{FitOD}(i, O D)]}$

正規化されたプロファイルである式(4)から不均一性 の補正係数である近似多項式 $F i t C F(i, O D)$ を求める.

$F i t C F(i, O D)=a(O D) x^{3}(i)+b(O D) x^{2}(i)+c(O D) x(i)+d$

係数 $a, b, c, d$ は各次数の係数で, $x(i)$ は走査垂直 方向のピクセル位置である. 式(5)の次数は, 二次式お よび三次式を提案し, 相関係数の值とプロファイルの形 状から, 三次式を選択した。

処方線量ごとに，また色ごとに前述の手順で式(5)を 
作成した，処方線量ごとに作成された式(5)は線量ごと に離散的な值となる。したがって，その線量間はcubic spline 法を用いて内挿し, 未補正画像に対して線量およ び位置ごとに不均一性の補正を行った。

本研究で利用したフィルム解析ソフトウェアには, 光 学濃度のプロファイルのための式(3)の係数, および不 均一性の補正を行うための正規化されたプロファイルの ための式(5)の係数を, 処方線量ごとに, また色ごとに 入力した.

(3)補正法の検証

本研究で作成した補正法を用いて, 走查垂直方向に おける不均一性の補正の効果を評価するために，いく つかのテストパターンを利用して検証を行った，検証方 法は, 下記の条件で I'mRT MatriXX およびEBT2 に照 射を行い, I'mRT MatriXX の測定值を基準値として, EBT2 の補正前と補正後の測定值の比較を行った。設 置条件は, I'mRT MatriXX およびEBT2 をファントムの 深さ $5 \mathrm{~cm}$ に設置し, $S S D$ を $100 \mathrm{~cm}$ に設定して照射を 行った，色成分は赤色成分を使用した．正規化は全条 件アイソセンタで行った。

\section{【条件 1】}

照射野：正方形 (Jaw サイズ : $\left.20 \times 20 \mathrm{~cm}^{2}\right)($ Fig. 2a)

処方線量 : $2.0 \mathrm{~Gy}$

\section{【条件 2】}

照射野：5段ステップ(Jawサイズ：30×22.5 $\left.\mathrm{cm}^{2}\right)$

(Fig. 2b)

処方線量: $2.5 \mathrm{~Gy}$

【条件 3】

\section{IMRT プラン}

前立腺プラン(処方線量 : $2.0 \mathrm{~Gy}$ )の 5 門中の 1 門： Jaw サイズ : $9.3 \times 7.6 \mathrm{~cm}^{2}$ (X 方向 : $4.5+4.8 \mathrm{~cm}, \mathrm{Y}$ 方向 : $3.8+3.8 \mathrm{~cm})($ Fig. 2c)

頭頸部プラン(処方線量 : $2.2 \mathrm{~Gy}$ )の 9 門中の 1 門 : Jaw サイズ : $14.0 \times 22.1 \mathrm{~cm}^{2}(\mathrm{X}$ 方向 : 6.4+7.5 cm, $\mathrm{Y}$ 方 向 : $12.3+9.8 \mathrm{~cm})($ Fig. 2d $)$

I'mRT MatriXX と EBT2 との比較には線量差の二次 元マップを利用し, I'mRT MatriXX と EBT2 のそれぞ れの色成分における測定值の pass ratio を比較した.

IMRT プランを代表とする線量分布の比較において，ガ ンマインデックスを用いた解析 ${ }^{29)}$ が多く利用されている が, JASTRO IMRT ガイドライン ${ }^{30)}$ ではガンマインデッ クスに関する許容值が設定されていないこと, また, ガ ンマインデックスを用いた評価の場合, フィルム画像上 の雑音がガンマインデックスの距離成分に影響し, そ の結果 pass ratio がよくなってしまう31)ことが考えられる ため, 上記の線量差のみの評価を行った。 また, 本研
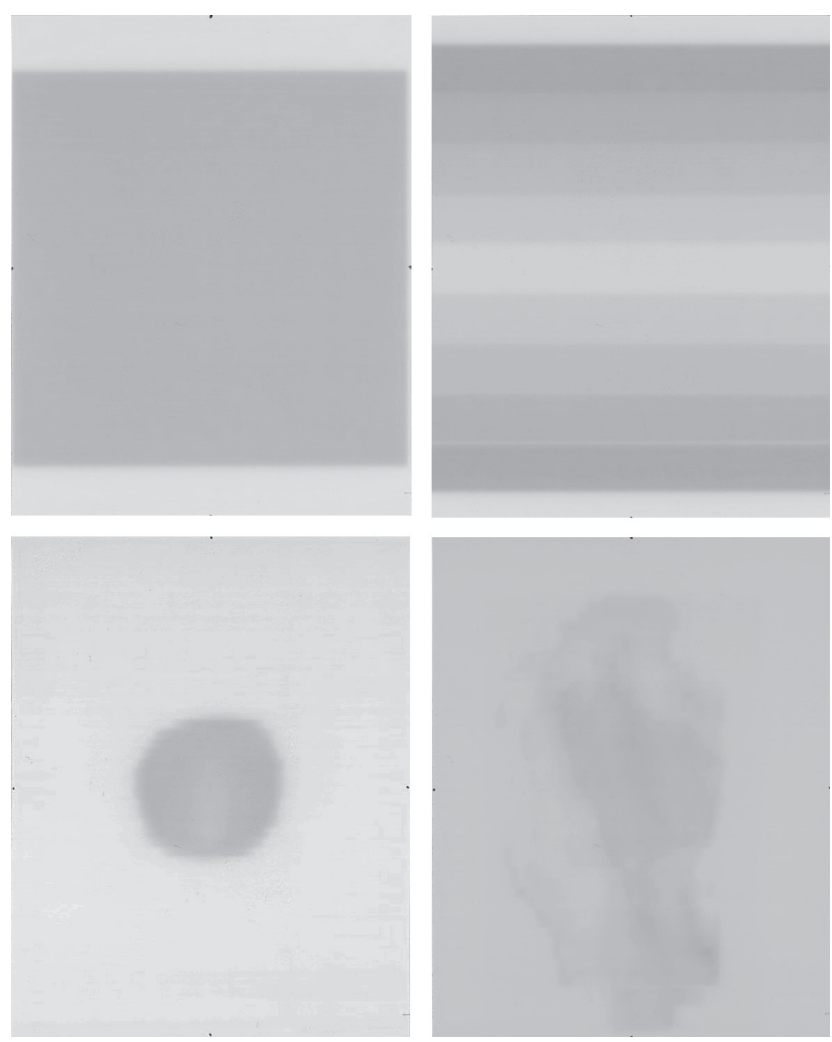

Fig. 2 Four images scanned by the scanner for: (a) square dose map (b) five-step dose pattern (c) dose map of a prostate IMRT plan (1 treatment field) (d) dose map of a head and neck IMRT plan (1 treatment field).

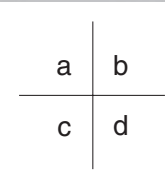

究では, 不均一性の補正ありと補正なしの相対的な比 較を行うため, dose differenceのみを用いた。 なお，本 研究で使用した治療計画データの使用に関しては, 個 人情報の保護に充分配慮し, 当施設の許可(院内倫理委 員会の承認)を得た。

\section{1-3 赤色成分および赤色/青色成分を用いた際の 測定精度の向上と走査垂直方向における補正 による影響の検証}

本研究で作成した不均一性の補正法において, 走査 垂直方向に扔ける不均一性が, 使用する色成分によっ て補正結果に影響を及ぼすかを検討し，それとともに red/blue correction 法の有効性についても検討した。本 研究で利用したフィルム解析ソフトウェアでは ISP 社か ら提案されている red/blue correction 法が実装されてお り,これを利用した ${ }^{26)}$. Red/blue correction 法は吸収又 ペクトルの特性を利用し，照射された EBT2 をフラット ベッドスキャナで読み取り, 画素を赤色/緑色/青色そ れぞれの色成分に分解し, 線量によって変化する(依存 する)赤色成分と線量によって変化しない青色成分を利 用する，赤色成分は線量の大小で画素值が変動する 

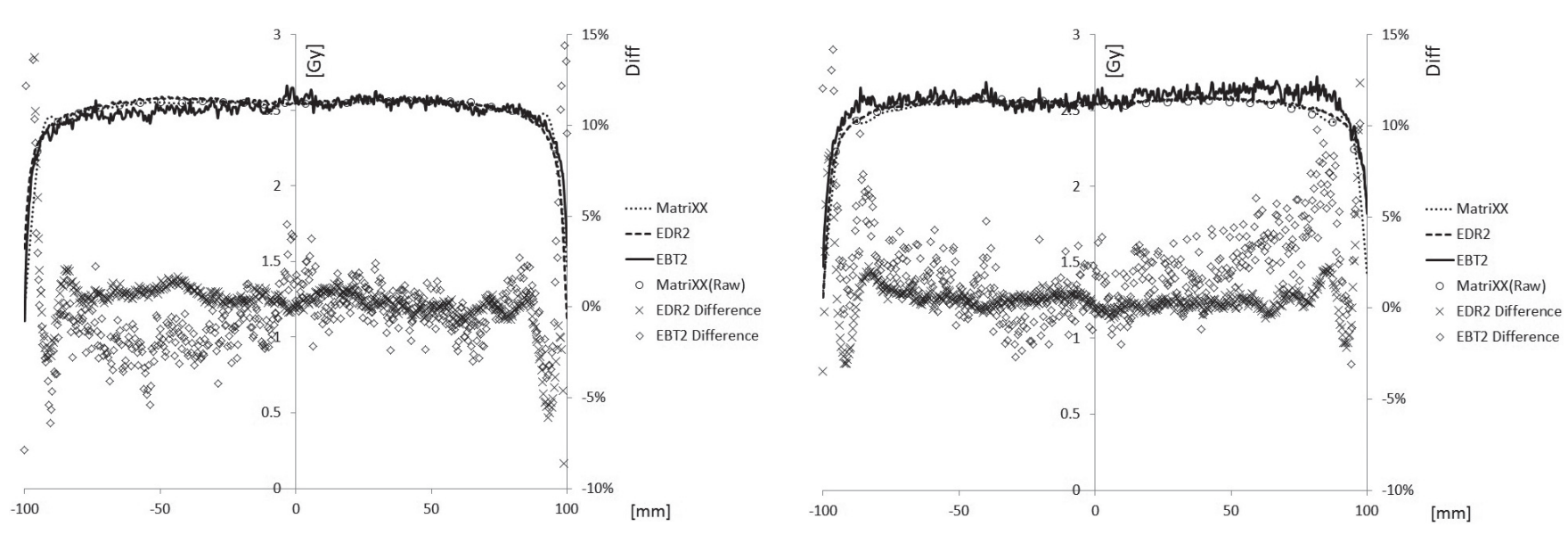

Fig. 3 Dose profiles on the central axis (a) perpendicular and (b) parallel to the scanner lamp movement axis [I'mRT MatriXX (the dotted line is interpolated from the circular dots)] and films [EDR2 (dashed line) and EBT2 (solid line)]. Differences in the dose values of EDR2 (cross-dot line) and EBT2 (diamond-dot line) are compared to the values of the two-dimensional array measurement.

が, 青色成分はEBT2自体の厚みやフィルムの感度を 左右する塗布などによって画素值が変動する。した がって, EBT2 上に不規則に存在している可能性があ る塗布ムラによる感度ムラなどの補正に有効であるとさ れる。照射条件として，Jawサイズが異なる正方形照 射野 $\left(10 \times 10 \mathrm{~cm}^{2}, 20 \times 20 \mathrm{~cm}^{2}\right.$, 処方線量はともに 2.0 Gy), IMRT プラン(方法 4 と同様の前立腺プランと頭 頸部プラン)を用いた。照射されたフィルムをスキャン した後, フィルム解析ソフトウェアを用いて画素情報を 色成分ごと(赤色，緑色，青色)に分割し，赤色/青色 成分の画像を作成した. I'mRT MatriXX の測定値を基 準值とし, その值と赤色成分㧍よび赤色/青色成分の EBT2の測定值とを比較した。その比較に扔いて，不均 一性の影響を補正したものと補正なしのものを加え, 行った，比較評価は方法 1-2 と同様，線量差の二次元 マップおよび pass ratio を用いて行った.

\section{2. 結 果}

2-1 EDR2 と EBT2 におけるフラットベッドスキャ ナの光学濃度に対する影響

I'mRT MatriXX を基準值とし, EDR2 と EBT2のア イソセンタ上に抢ける線量プロファイルを比較した.

Fig. 3aに示したように走查水平方向の線量プロファイ ルの結果は, EDR2では1\%以内で一致し, EBT2では $-3 \%$ か $+3 \%$ の線量差が認められた。また, Fig. $3 b$ に 示したように走査垂直方向の線量プロファイルの結果 は, EDR 2 では $1 \%$ 以内で一致し, EBT2では $+3 \%$ 以 上, 最大で $+8 \%$ 程度の線量差が認められた。特に, EBT2 では走査方向の中央に対して辺縁へ進んでいくほ ど線量差が大きくなる傾向がみられた，両者の結果に
おいて, 基準值であるI'mRT MatriXX の測定值と, EDR2 とEBT2の測定值からそれぞれの線量差を求 め, EDR2 と EBT2 の線量差を $\mathrm{t}$ 検定した結果, EDR2 と EBT2 の両者に有意差が生じた(走査水平方向： $\mathrm{p}<0.0001$, 走査垂直方向 : $p<0.0001)$.

\section{2-2 EBT2の走査垂直方向における不均一性を補 正する方法}

SSD を $140 \mathrm{~cm}$ に設定して EBT2 に異なる線量を照射 した. SSD：140 cm での平坦度を確認するため, I'mRT MatriXX を利用して測定したところ，102.77\%となり， プロファイルの形はビーム中心軸に対して若干非対称に なった．階段状の光学濃度を有する(異なる処方線量が 照射された)フィルムを取得し，そのフィルムを利用し て, 処方線量ごとのスキャナ光源の走査方向に対する 垂直方向の光学濃度のプロファイルを測定した. Fig. 4 に(a) 赤色 $(b)$ 緑色 (c) 青色の光学濃度のプロファイルを 示した. 不均一性の傾向は, Fig. 4 に示したように処方 線量ごとに異なった，そのプロファイルを利用して，そ のプロファイルに一致する近似多項式を求めた．各プロ ファイルに関して二次多項式および三次多項式を求め, その相関係数を求めた，相関係数の平均值は二次式が $r=0.977 \pm 0.102$ となり, 三次式が $r=0.984 \pm 0.122$ となっ た。両者の近似式は高い一致を示していたが，三次式 の相関係数が二次式より高く，またプロファイルが非対 称であったことから，本研究では三次式を採用すること とした(Fig. 5).

\section{2-3 補正法の検証}

各照射条件において EBT2 および I'mRT MatriXX に 

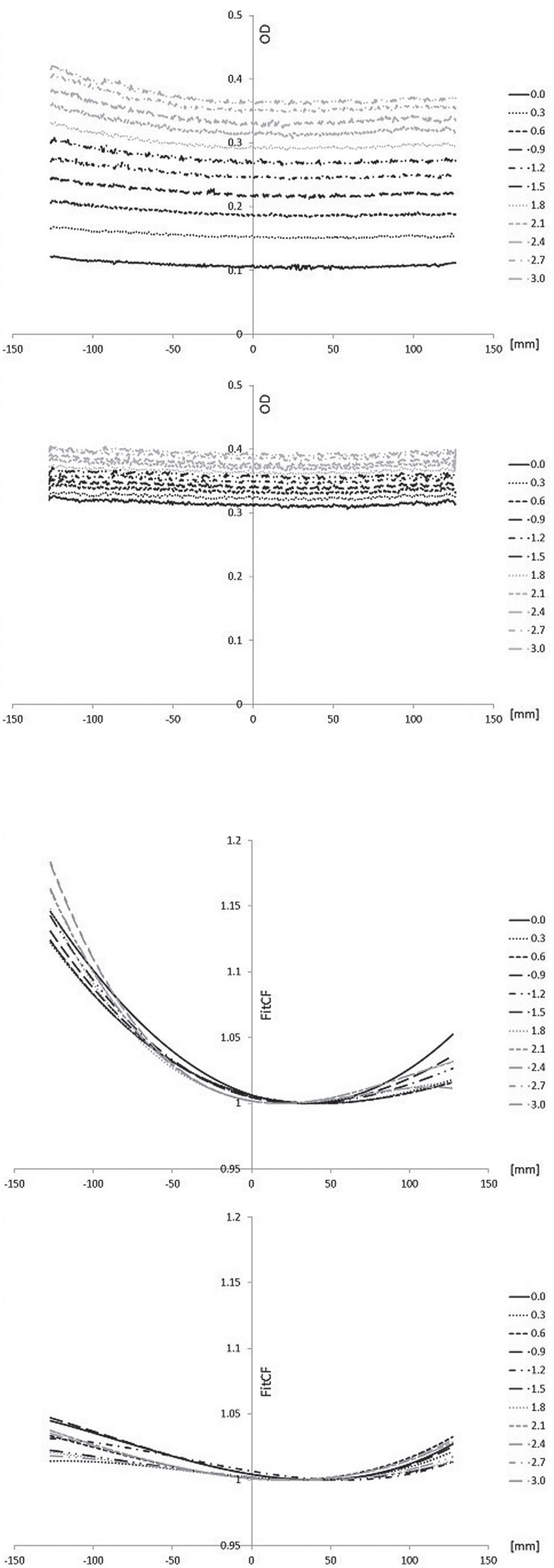
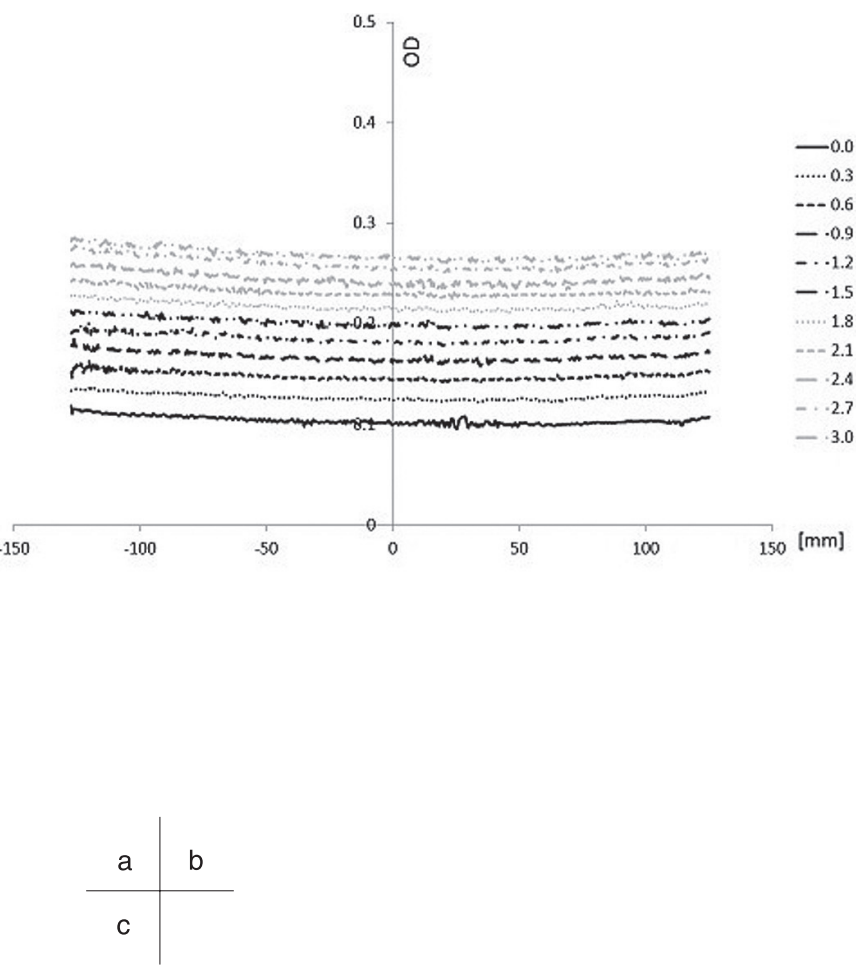

Fig. 4 Optical density profiles of different prescribed doses on the central axis perpendicular to the scanner lamp movement axis for (a) the red component (b) the green component and (c) the blue component.
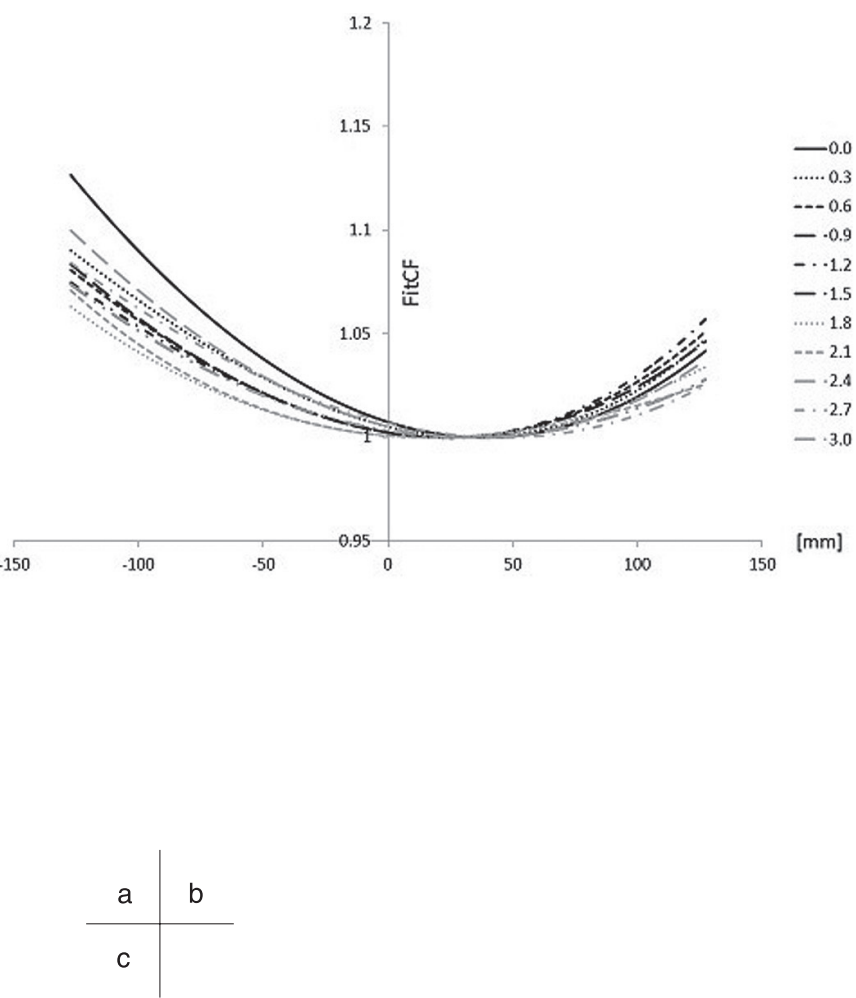

Fig. 5 Correction factor curves of different prescribed doses generated using a third-order polynomial fit for (a) the red component (b) the green component (c) the blue component. 


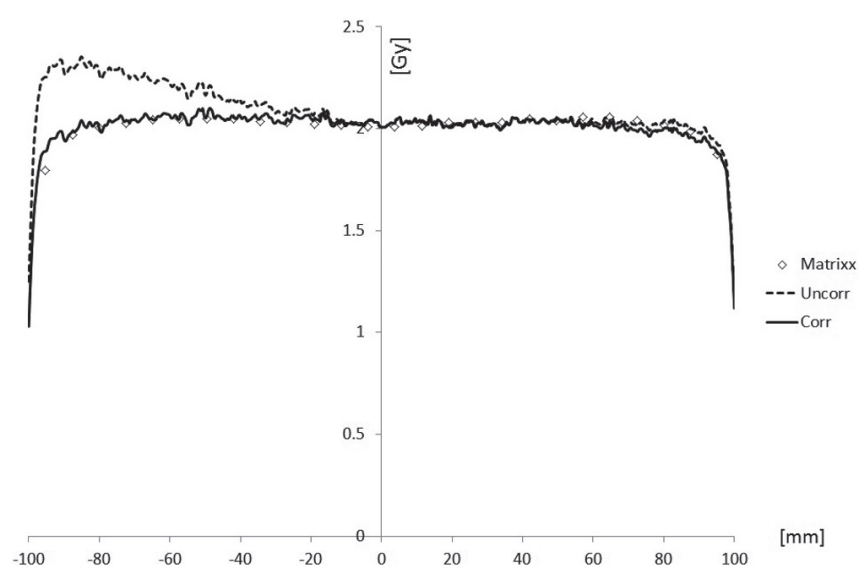

Fig. 6 Dose profiles of a square field $\left(20 \times 20 \mathrm{~cm}^{2}\right)$.

Dose profiles of two-dimensional array measurements and EBT2 film, on the central axis perpendicular to the scanner lamp movement axis. Dashed line: uncorrected film; solid line: corrected film.

照射を行い, EBT2 のアイソセンタ上における走査垂直 方向のプロファイル，および I'mRT MatriXX の同一軸 のプロファイルを取得したそそのプロファイルを利用 し, I'mRT MatriXX の測定值を基準值として, EBT2の 補正前と補正後の測定值の比較を行った．走查垂直方 向のプロファイルのグラフは, 縦軸が測定值 $(\mathrm{Gy})$, 横 軸がビーム中心軸からの距離，またスキャナ光源の中央 からの距離 $(\mathrm{mm})$ を示した。

条件(1)の正方形照射野に打けるプロファイルの結果 を Fig. 6 に示した. I’mRT MatriXXの測定值との線量 差は， $-90 \mathrm{~mm}$ 付近で補正前は $17.39 \%$ であったが，補 正後は $1.18 \%$ となった，照射野の中央部分の線量差 は，補正前が $2.01 \%$ ，補正後が $2.01 \%$ となり，補正に よって変わる必要のないところに抏いて，変化がないこ とがわかった。

条件(2)の 5 段ステップの照射野におけるプロファイ ルの結果を Fig. 7 に示した. I'mRT MatriXX の測定值

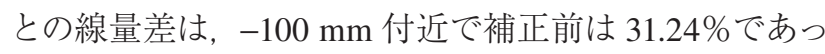
たが，補正後は $3.30 \%$ となた。 その他の異なる処方 線量が照射された位置においても, 補正前後での線量 差の向上がみられ，I'mRT MatriXX の測定值によって 一致する結果となった.

条件(3)の IMRT プラン(前立腺)に抢けるプロファイ ルの結果を Fig. 8a に示した. I'mRT MatriXX との線量 差は, $-30 \mathrm{~mm}$ 付近で補正前は $1.22 \%$, 補正後は $-1.34 \%$ ，また， $30 \mathrm{~mm}$ 付近で補正前は $-4.20 \%$, 補正 後は-3.68\%となった。条件(1), (2)の結果と比べ, 補正 前後での線量差の有意な向上はみられなかった。 ま た, IMRT プラン(前立腺)に扔ける線量差の二次元マッ

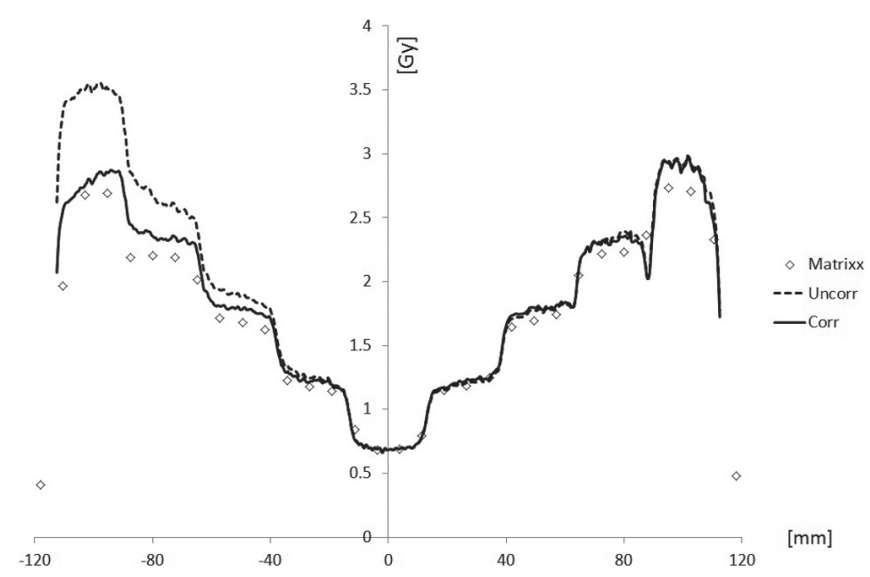

Fig. 7 Dose profiles of the five-step dose pattern treatment field $\left(30 \times 22.5 \mathrm{~cm}^{2}\right)$.

Dose profiles of two-dimensional array measurements and EBT2 film, on the central axis perpendicular to the scanner lamp movement axis. Dashed line: uncorrected film; solid line: corrected film.

プおよび pass ratio を求めた，線量差の二次元マップの 結果を Fig. 8b, c に示した. Pass ratioは, 補正前は $47.22 \%$, 補正後は $45.06 \%$ となった。補正後にpass ratio が $2 \%$ 程度低下したが, 走査垂直方向に扔ける照 射野外の上方部分 (Fig. 8b，c で上の部分)に拈いて, 補 正前は許容值を超える領域がみられたが，補正後は許 容值以内に収まる結果となった。

条件(3)の IMRT プラン(頭頸部)におけるプロファイ ルの結果を Fig. 9a に示した. I'mRT MatriXX との線量 差は, $-90 \mathrm{~mm}$ 付近で補正前は $22.88 \%$, 補正後は $1.97 \%$ となった。 また, IMRT プラン(頭頸部)における 線量差の二次元マップおよび pass ratio を求めた。線量 差の二次元マップの結果を Fig. 9b, c に示した. Pass ratioは, 補正前は $59.84 \%$, 補正後は $60.78 \%$ となっ た．走査垂直方向に扔ける照射野辺縁 (Fig. 9b, c で上 と下の部分)において, 補正前は許容值を超える領域 がみられたが，補正後は許容值以内に収まる領域が増 加した。 また，30\%から50\%の線量域(Fig.9aにおけ る-90 mm 付近の線量域にに扔ける pass ratioは, 補正 前は $48.42 \%$, 補正後は $63.82 \%$ となった。

\section{2-4 赤色成分および赤色/青色成分を用いた際の 測定精度の向上と走查垂直方向における補正 による影響の検証}

フィルム解析ソフトウェアにて EBT2 の測定フィルム を色成分ごと(赤色, 緑色, 青色)に分割し, 赤色成分 および赤色 / 青色成分の二次元線量分布測定デー夕を それぞれ作成した，さらに，それらの赤色成分拉よび赤 色 / 青色成分の二次元線量分布測定デー夕に対して不 


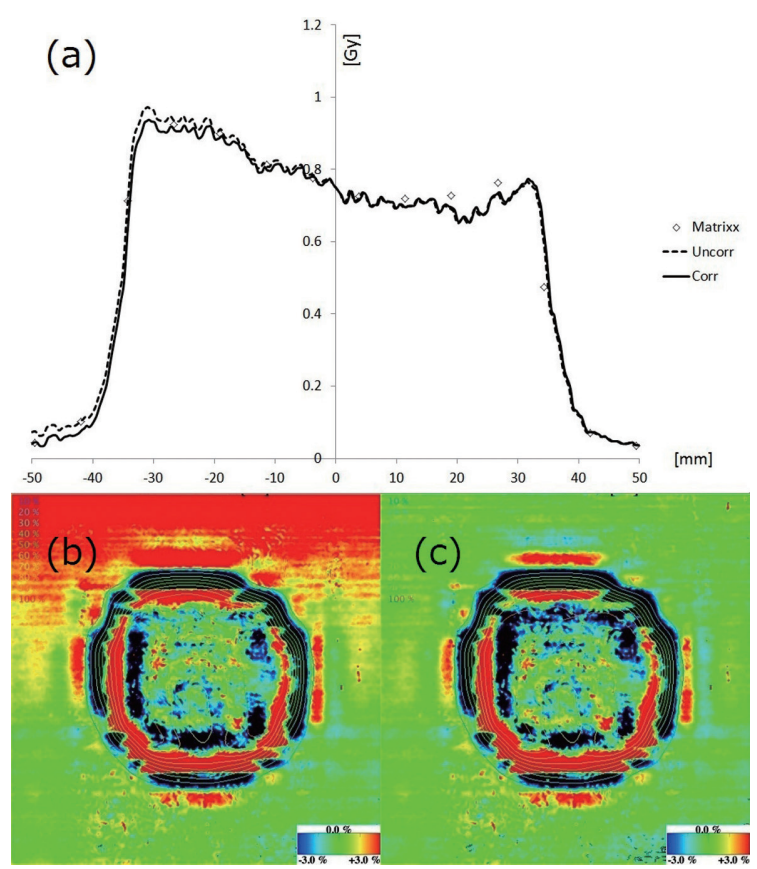

Fig. 8 Dose profiles and two-dimensional dose difference maps of a prostate IMRT plan.

(a) Dose profiles of two-dimensional array measurements and EBT2 film, on the central axis perpendicular to the scanner lamp movement axis. Dashed line: uncorrected film; solid line: corrected film. Two-dimensional dose difference maps for the uncorrected film (b) and the corrected film (c), shown compared to the twodimensional array measurement.

均一性の補正法を考慮したデー夕と考慮していない デー夕を作成した。それら作成したデータとI'mRT MatriXXで測定したデー夕を比較し, 線量差を求め た。この際, I'mRT MatriXX で測定したデータを基準 值として，正規化は補正前と補正後で同じ位置で行っ た，走査垂直方向のプロファイルのグラフは，縦軸が測 定值 $(\mathrm{Gy})$, 横軸がビーム中心軸からの距離, またス キャナ光源の中央からの距離 $(\mathrm{mm})$ を示した.

正方形照射野 $\left(10 \times 10 \mathrm{~cm}^{2}\right)$ におけるプロファイルと線 量差の二次元マップの結果を Fig. 10(赤色成分), Fig. 11 (赤色 / 青色成分)に示した. Pass ratio は, 赤色成分で は補正前は $17.27 \%$, 補正後は $18.29 \%$ となり, 赤色/青 色成分では補正前は $17.26 \%$, 補正後は $18.11 \%$ となっ た。両者とも同程度であったが, 補正によって $1 \%$ 程度 向上した. I'mRT MatriXX との線量差は, $-35 \mathrm{~mm}$ 付 近で，赤色成分では補正前は $3.98 \%$ ，補正後は $0.12 \%$ となり，赤色/青色成分では補正前は $2.53 \%$, 補正後 はー0.68\%となった。

正方形照射野 $\left(20 \times 20 \mathrm{~cm}^{2}\right)$ におけるプロファイルと線 量差の二次元マップの結果を Fig. 12(赤色成分), Fig. 13 (赤色 / 青色成分)に示した. Pass ratioは, 赤色成分で は補正前は $18.45 \%$, 補正後は $25.30 \%$ となり, 赤色 / 青

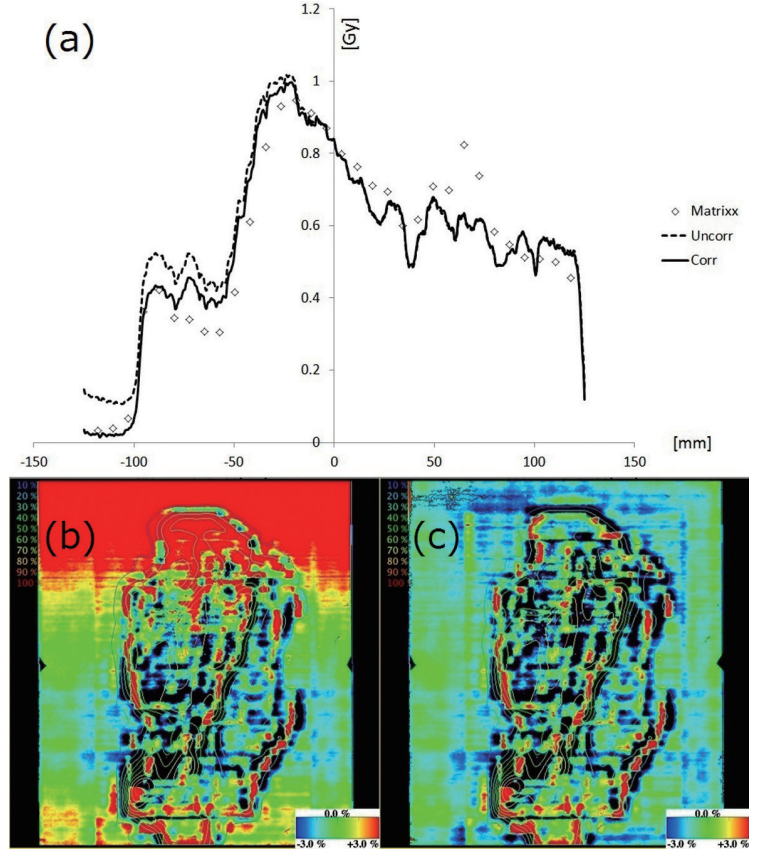

Fig. 9 Dose profiles and two-dimensional dose difference maps of a head and neck IMRT plan.

(a) Dose profiles of two-dimensional array measurements and EBT2 film, on the central axis perpendicular to the scanner lamp movement axis. Dashed line: uncorrected film; solid line: corrected film. Two-dimensional dose difference maps for the uncorrected film (b) and the corrected film (c), shown compared to the twodimensional array measurement.
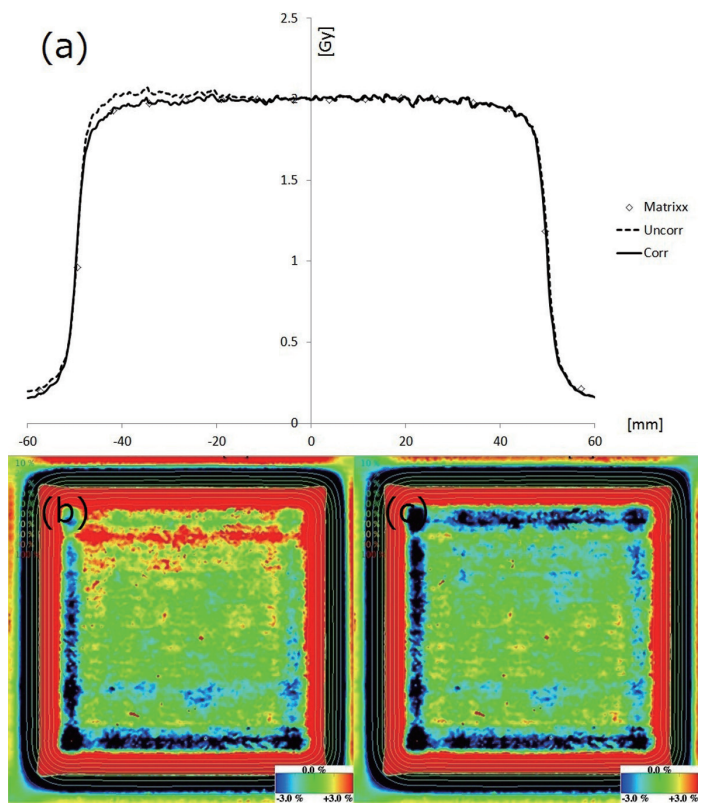

Fig. 10 Dose profiles and two-dimensional dose difference maps of the square treatment field $\left(10 \times 10 \mathrm{~cm}^{2}\right)$ of the red component.

(a) Dose profiles of two-dimensional array measurements and EBT2 film, on the central axis perpendicular to the scanner lamp movement axis. Dashed line: uncorrected film; solid line: corrected film. Twodimensional dose difference maps for the uncorrected film (b) and the corrected film (c), shown compared to the two-dimensional array measurement. 

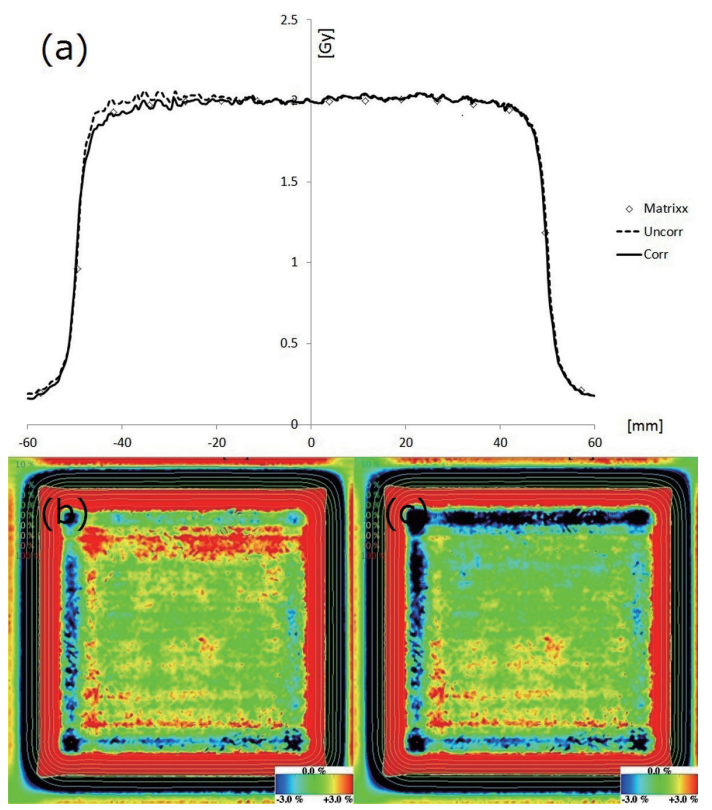

Fig. 11 Dose profiles and two-dimensional dose difference maps of the square treatment field $\left(10 \times 10 \mathrm{~cm}^{2}\right)$ of the red/blue component.

(a) Dose profiles of two-dimensional array measurements and EBT2 film, on the central axis perpendicular to the scanner lamp movement axis. Dashed line: uncorrected film; solid line: corrected film. Twodimensional dose difference maps for the uncorrected film (b) and the corrected film (c), shown compared to the two-dimensional array measurement.

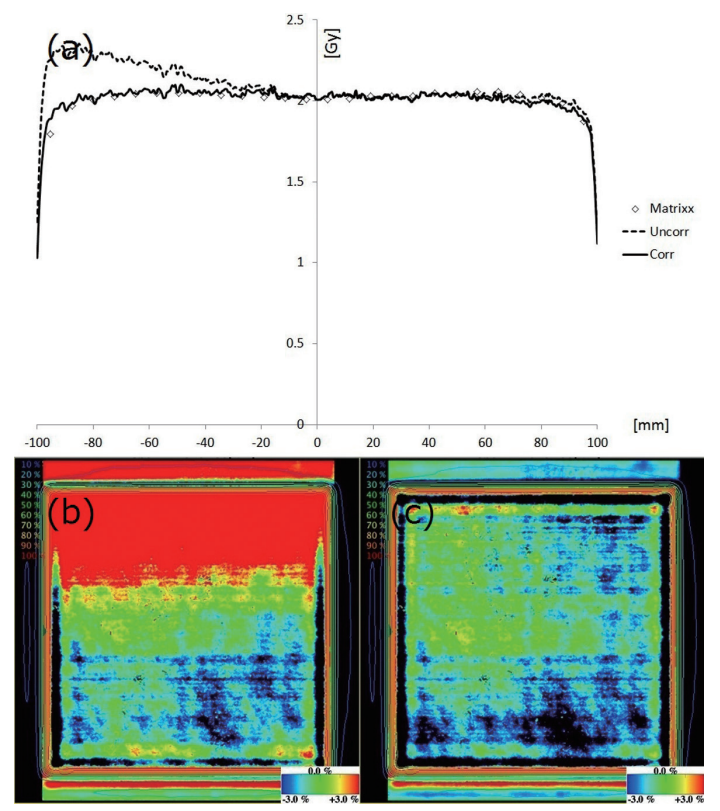

Fig. 12 Dose profiles and two-dimensional dose difference maps of the square treatment field $\left(20 \times 20 \mathrm{~cm}^{2}\right)$ of the red component.

(a) Dose profiles of two-dimensional array measurements and EBT2 film, on the central axis perpendicular to the scanner lamp movement axis. Dashed line: uncorrected film; solid line: corrected film. Twodimensional dose difference maps for the uncorrected film (b) and the corrected film (c), shown compared to the two-dimensional array measurement.

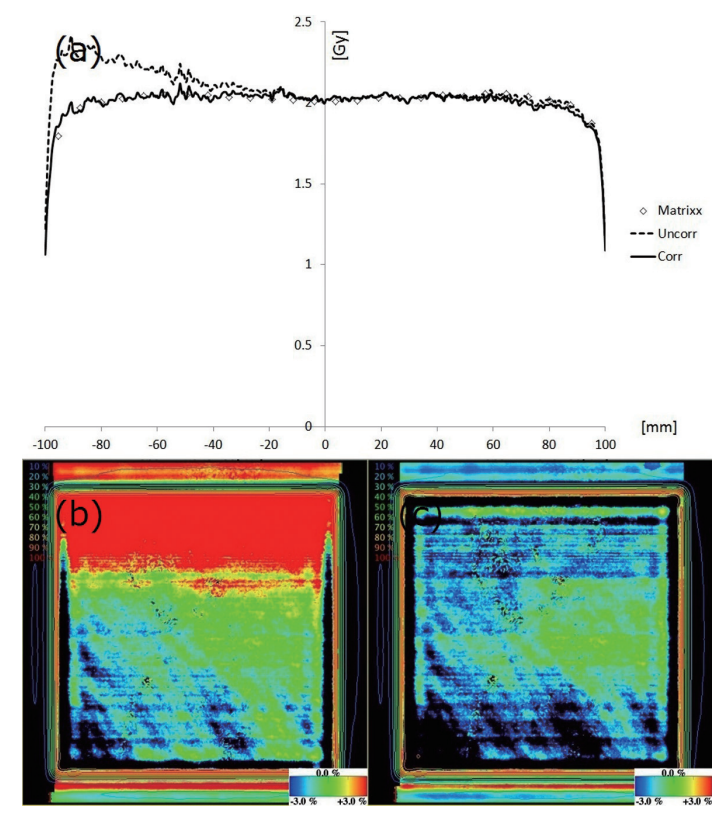

Fig. 13 Dose profiles and two-dimensional dose difference maps of the square treatment field $\left(20 \times 20 \mathrm{~cm}^{2}\right)$ of the $\mathrm{red} / \mathrm{blue}$ component.

(a) Dose profiles of two-dimensional array measurements and EBT2 film, on the central axis perpendicular to the scanner lamp movement axis. Dashed line: uncorrected film; solid line: corrected film. Twodimensional dose difference maps for the uncorrected film (b) and the corrected film (c), shown compared to the two-dimensional array measurement.

色成分では補正前は $19.26 \%$, 補正後は $30.07 \%$ となっ た，補正によって両者とも10\%程度向上し，また，赤 色/青色成分は赤色成分に比べ，補正前は $1 \%$ 程度, 補正後は $5 \%$ 程度が高くなった. I'mRT MatriXX との 線量差は, $-90 \mathrm{~mm}$ 付近で, 赤色成分では補正前は $17.39 \%$ ，補正後は $1.18 \%$ となり，赤色/青色成分では 補正前は $15.85 \%$ ，補正後は-1.00\%となった。

IMRT プラン(前立腺)に扔けるプロファイルと線量差 の二次元マップの結果を Fig. 14(赤色成分), Fig. 15(赤 色/青色成分)に示した. Pass ratioは，赤色成分では補 正前は $47.22 \%$, 補正後は 45.06\%となり, 赤色 / 青色成 分では補正前は $49.18 \%$ ，補正後は $48.64 \%$ となった。 補正によって両者とも2\%程度低下し，また，赤色／青 色成分は赤色成分に比べ，補正前は $2 \%$ 程度，補正後 は4\%程度が高くなった. I'mRT MatriXX との線量差 は， $-30 \mathrm{~mm}$ 付近で，赤色成分では補正前は $1.22 \%$, 補 正後は $-1.34 \%$ となり，赤色/青色成分では補正前は $2.69 \%$, 補正後は 1.69\%となった。

IMRT プラン(頭頸部)におけるプロファイルと線量差 の二次元マップの結果を Fig. 16(赤色成分), Fig. 17(赤 色 / 青色成分)に示した. Pass ratio は，赤色成分では補 正前は $59.84 \%$, 補正後は $60.78 \%$ となり, 赤色/青色 


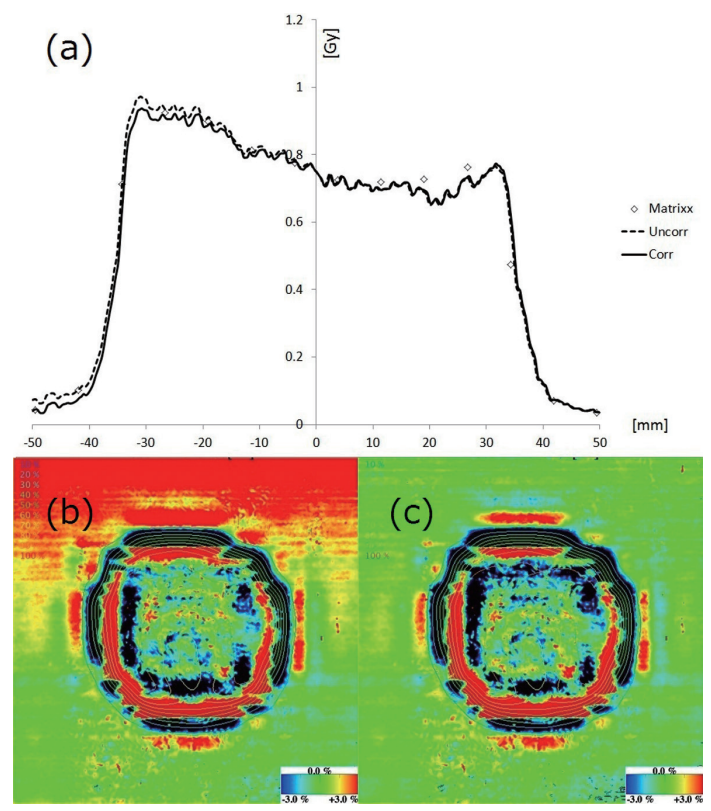

Fig. 14 Dose profiles and two-dimensional dose difference maps of the treatment field of the prostate IMRT plan of the red component.

(a) Dose profiles of two-dimensional array measurements and EBT2 film, on the central axis perpendicular to the scanner lamp movement axis. Dashed line: uncorrected film; solid line: corrected film. Twodimensional dose difference maps for the uncorrected film (b) and the corrected film (c), shown compared to the two-dimensional array measurement.
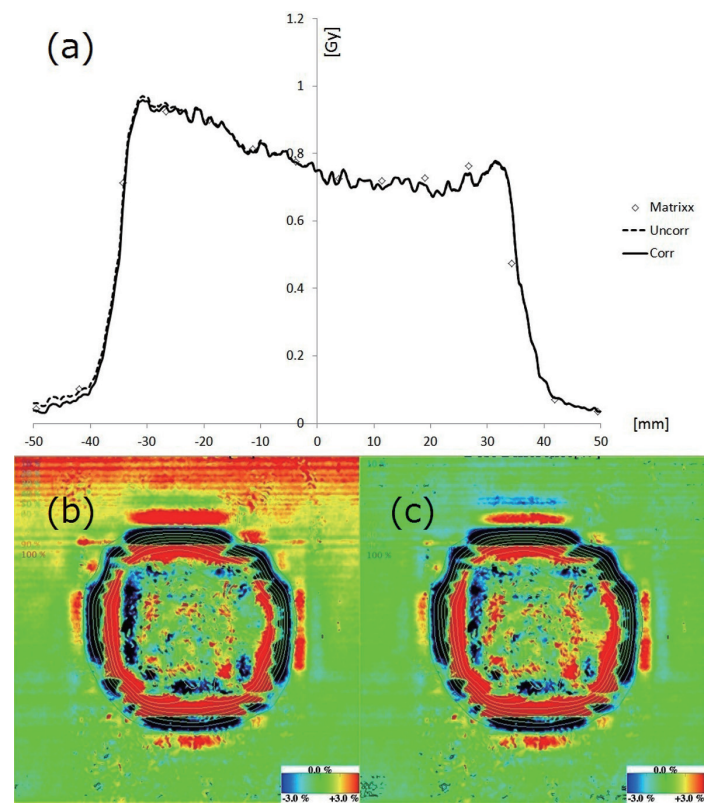

Fig. 15 Dose profiles and two-dimensional dose difference maps of the treatment field of a prostate IMRT plan of the red/blue component.

(a) Dose profiles of two-dimensional array measurements and EBT2 film, on the central axis perpendicular to the scanner lamp movement axis. Dashed line: uncorrected film; solid line: corrected film. Twodimensional dose difference maps for the uncorrected film (b) and the corrected film (c), shown compared to the two-dimensional array measurement.
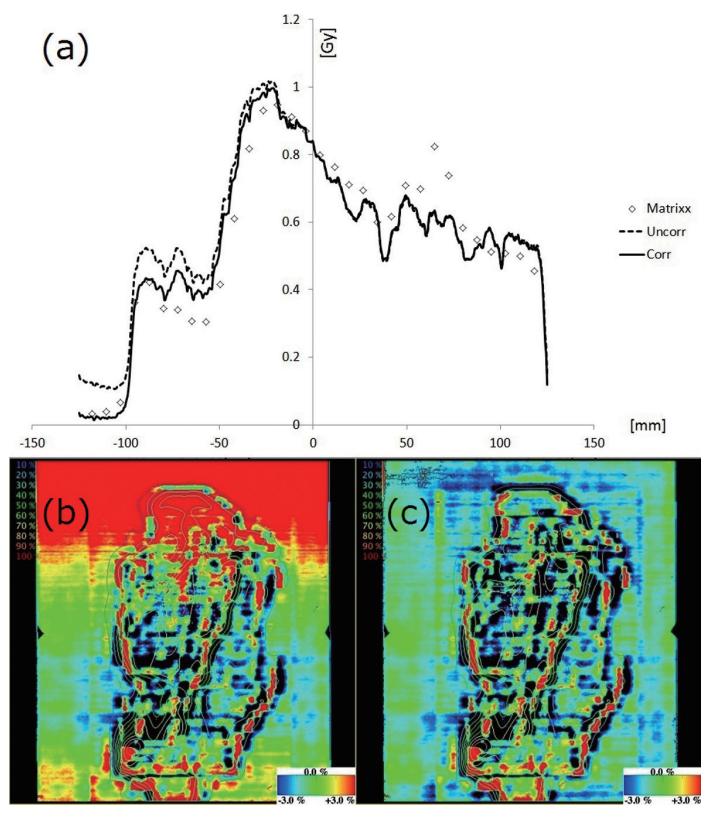

Fig. 16 Dose profiles and two-dimensional dose difference maps of the treatment field of the head and neck IMRT plan of the red component.

(a) Dose profiles of two-dimensional array measurements and EBT2 film, on the central axis perpendicular to the scanner lamp movement axis. Dashed line: uncorrected film; solid line: corrected film. Twodimensional dose difference maps for the uncorrected film (b) and the corrected film (c), shown compared to the two-dimensional array measurement.

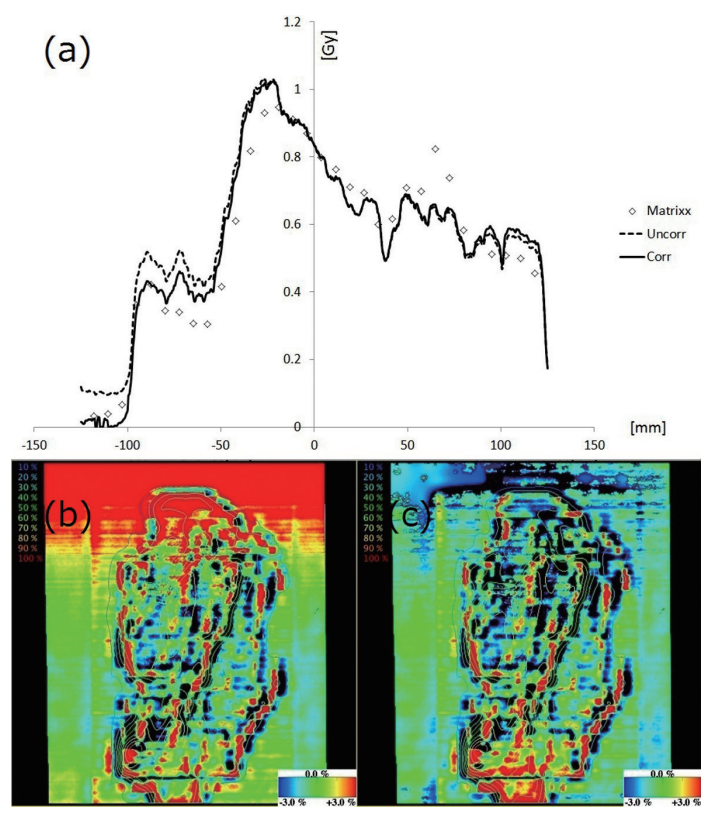

Fig. 17 Dose profiles and two-dimensional dose difference maps of the treatment field of the head and neck IMRT plan of the red/blue component.

(a) Dose profiles of two-dimensional array measurements and EBT2 film, on the central axis perpendicular to the scanner lamp movement axis. Dashed line: uncorrected film; solid line: corrected film. Twodimensional dose difference maps for the uncorrected film (b) and the corrected film (c), shown compared to the two-dimensional array measurement. 


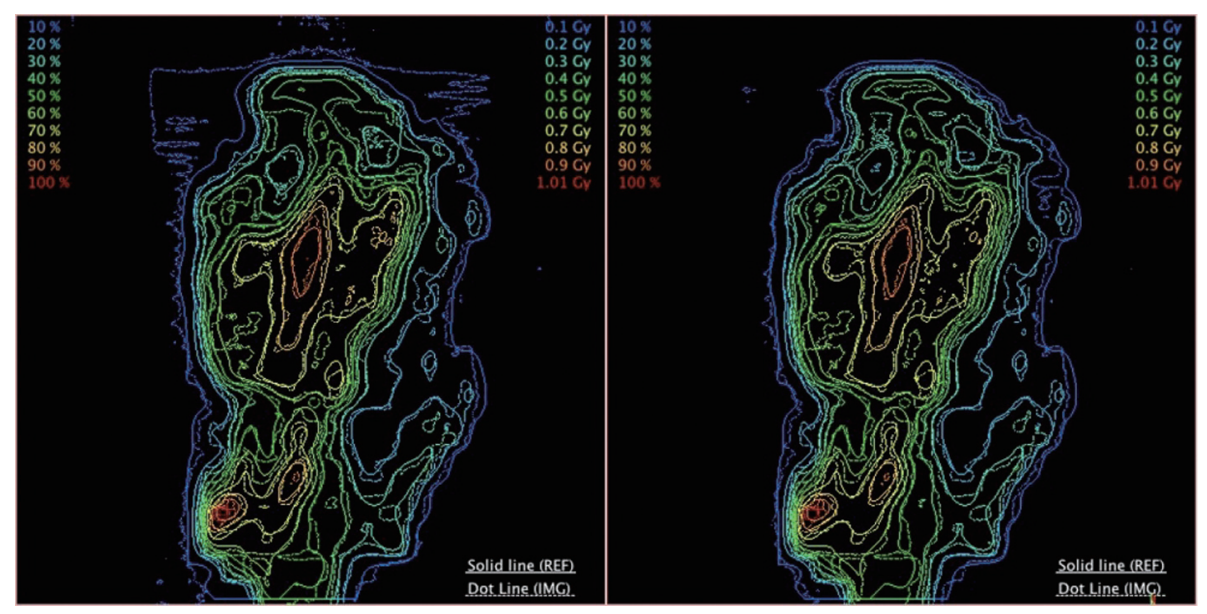

Fig. 18 Isodose curves of the treatment field of a head and neck plan for two-dimensional array measurements (solid line) and the EBT2 film (dotted line), without correction (left) and with correction (right).

成分では補正前は $67.89 \%$, 補正後は $63.57 \%$ となっ た，補正によって赤色成分は $1 \%$ 程度向上し，赤色 / 青 色成分は 4\%程度低下した。 また，赤色/青色成分は赤 色成分に比べ, 補正前は $8 \%$ 程度, 補正後は $3 \%$ 程度高 くなった，赤色 / 青色成分に関して，走查垂直方向に拀 ける照射野辺縁 (Fig. 17b, c で上の部分)において, 補 正前は許容值を超える領域がみられたが，補正後は許 容值以内に収まる領域が増加した。また，0\%から 30\% の線量域(Fig. 17b, c で上の部分の線量域)における pass ratio は, 補正前は $72.89 \%$, 補正後は $77.91 \%$ とな り，視覚的にも pass ratioでも補正後に改善がみられ た.しかし，本検証で用いた IMRT プラン(頭頸部)の 等線量曲線(Fig. 18)に示したように，照射野内に線量勾 配が急峻な領域が多く, その急峻な領域において補正 前後で視覚的に変化が起きたとは判断できないが, pass ratio が低下した. I'mRT MatriXX との線量差は，-90 mm 付近で, 赤色成分では補正前は $22.88 \%$, 補正後は $1.97 \%$ となり，赤色/青色成分では補正前は $20.12 \%$, 補 正後は $0.63 \%$ となった. $30 \%$ から $50 \%$ の線量域(Fig. 17a に扮ける $-90 \mathrm{~mm}$ 付近の線量域)における pass ratio は，赤色成分では補正前は $48.41 \%$, 補正後は $62.82 \%$ となり, 赤色/青色成分では補正前は $56.53 \%$, 補正後 は 60.59\%となった。

\section{3. 考 察}

本研究では，まずEDR2 と EBT2 の走査水平方向， 走査垂直方向に打ける光学濃度に対する影響を, I'mRT MatriXX を基準值として線量差を求め, 評価し た。 その結果, 走查水平方向に関して, EDR2 と EBT2 との線量差に有意差がみられ, EBT2の線量差は有意
に精度の低下を示した，これは，EBT2 の線量差の傾向 として照射野中央打よび辺縁に均等に $3 \%$ 程度の線量 差が分散している傾向であったことから，スキャナ光源 の影響も考えられるが, EBT2 固有のロットごとの感光 物質の塗布ムラが影響していると考えられる19)。また， 走査垂直方向に関しても, EDR2 と EBT2 との線量差に 有意差が生じた。これは, EBT2の線量差の傾向として 中央に比べ辺縁に進むほど線量差が大きくなり，この傾 向は Menegotti らの報告 ${ }^{21)}$ と一致することから，スキャ ナ光源による影響が当院で使用しているフラットベッド スキャナと EBT2 との組み合わせに抏いて同様に生じた と考えられる.

当院で使用しているフラットベッドスキャナと EBT2 を組み合わせて利用した際, 不均一性の補正に用いた フィルムのプロファイルは, 走査垂直方向に执いて, 線 量差の傾向が中心から辺縁に行くに従って大きくなり, ビーム中心軸，またスキャナ光源の中央に対して若干非 対称となった，本研究では，補正関数を求めるための フィルムの光学濃度のプロファイルを測定する際, SSD を $140 \mathrm{~cm}$ に設定し，できる限り平坦なプロファイルを 得て，フラットベッドスキャナの影響のみを抽出した補 正関数を作成するよう試みた。しかし, SSD：140 cm で のプロファイルをI'mRT MatriXX で測定した際, プロ ファイルは非対称になり平坦度は約 103\%となった。こ の結果はEBT2 に照射されたプロファイルに対応すると 考えると, プロファイルが非対称になった原因は, SSD：140 cm を利用したことによって，アイソセンタの 設定の際にクロスワイヤを利用したが，ぼけてしまい， 中心軸の設定がずれたためであると考えられる，加え

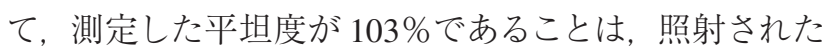


線量プロファイルが $3 \%$ 程度の平坦ではないということ であり，その分が補正関数の精度の悪化につながると 考えられる. しかし，この3\%の誤差を含んだ補正関数 を利用しても, 結果で得られた不均一性の補正による プロファイルの一致度の向上や pass ratio の向上が得ら れたことはフラットベッドスキャナの影響が平坦度の誤 差以上に影響していることを示しており, 不均一性の補 正が有効であると考えられる。 しかしながら，不均一性 の補正の精度を向上させるにはさらに大きな SSD を利 用する必要があり, 大きな SSDを利用して正確に測定 を行うための方法を講じる必要があると考えられる。ま

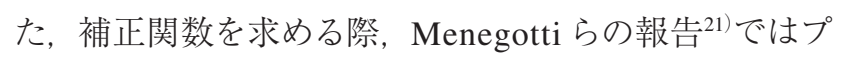
ロファイルの傾向が対称となったため, 不均一性の補正 関数として二次式を用いたと考えられるが, 本研究では 三次式が最も一致した。 これは, 取得したプロファイル が非対称であったことや，本研究ではEBT2を使用し ており, Menegottiらが使用したEBTとは素材や構成 が異なることや, Hartmann らの同一フィルム内でも部 位によって感度が不均一であるとの報告 ${ }^{19}$ や橘らの報 告 ${ }^{31}$ も考慮すると, EBT2 に特有の感光物質の塗布ムラ の影響がこのプロファイルに含まれることが原因である とも考えられる.

$20 \times 20 \mathrm{~cm}^{2}$ の正方形照射野㧍よび $30 \times 22.5 \mathrm{~cm}^{2}$ の 5 段 ステップ, IMRT プラン(頭頸部)は, 不均一性の補正前 後での線量差の向上がみられ, 基準值である I'mRT MatriXX の測定值とより一致する結果を示した。 しか し, IMRT プラン(前立腺)は補正前後で補正による高い 一致性を示さなかった，その原因は，その他三つのプラ ンと比べ照射野が小さいため, 補正による効果が少な いと考えられる. 本研究で取得した補正関数のプロファ イルからもわかるように，スキャナの影響は走査垂直方 向の中心から辺縁にかけて大きくなっていた. IMRT プ ラン(前立腺)の評価部分は走査垂直方向の $\pm 5 \mathrm{~cm}$ 以内 の範囲となっていた，その範囲は，スキャナの中央部に あたり, 補正関数のプロファイルを見ると約 $3 \%$ 以下の 補正係数となっていたことから, 補正による効果が小さ かったと考えられる。したがって, スキャナの影響は走 査垂直方向の中心から辺縁にかけて大きくなることか ら, 比較的大きな照射野のプランに関しては, 効果的な 不均一性の補正を行うことで, 線量分布解析の精度を 向上できると考えられる.

赤色成分および赤色/青色成分を用いた際に, 色成 分ごとに不均一性の補正による影響が生じるかを評価 した．赤色成分および赤色／青色成分の pass ratio は, 不均一性の補正を行う前後で同等であり, 小さな照射 野の場合は補正による効果は小さく, 大きな照射野の
場合は補正による効果は大きかった。このことから，不 均一性の補正は, 赤色成分および赤色/青色成分のど ちらを利用しても線量分布解析の精度に同程度の向上 をもたらすと考えられる，また，赤色成分および赤色／ 青色成分が基準值である I'mRT MatriXX に対してより 近い值になるか，すなわち測定精度が高いかを評価し た. 赤色 / 青色成分の pass ratioは, 赤色成分の pass ratio と比較して同等か $5 \%$ 程度向上した. Pass ratio が 向上した理由として, 赤色/青色成分を利用したことに よって，塗布ムラによる感度ムラを補正できたことがあ げられる。塗布ムラによる感度ムラは EBT2 のフィルム 中に不規則的に存在しているため, フラットベッドス キャナによる不均一性の影響を補正する方法では補正 できない, そのため, 本研究の不均一性の補正法と red/blue correction 法を組み合わせたことでさらに pass ratioが向上したと考えられる，ただし，赤色/青色成 分を用いた場合のIMRT プラン(頭頸部)に限っては, 補正後に pass ratio が低下した. ビーム中心軸から離れ た領域に挍いては pass ratioが改善され, 視覚的に許容 值以内に収まる領域が増加し, 補正後の方が改善され たと判断できた。しかし，本検証で用いた IMRT プラン (頭頸部) は線量勾配が急峻な領域が多く, 線量差の許 容值が達成しにくいうえ，その急峻な領域においては補 正係数に対する線量差の感度が高いと考えられる。 ま た, 二次元多列検出器のデータが離散的な值のため, 空間分解能にも問題があったと考えられ，そのため pass ratioが低下したと考えられる。 このことから, red/blue correction 法による測定精度は, 同等もしくは若干向上

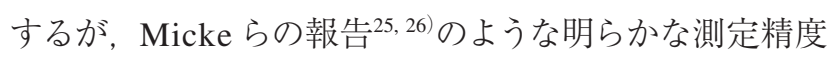
の向上はみられなかった。この原因として, Mickeらが 利用したEBT2 と本研究で利用したEBT2のフィルム 特性が厳密にいうと異なることが影響していると考えら れる。すなわち, EBT2 はフィルムロットごと(開発時期 の違いなど)によってフィルム作成のプロセスなどが異 なり，フイルム自体の精度が異なることが報告されてお り ${ }^{19)}$ ，フィルムの塗布ムラに由来する感度ムラなどが影 響し, red/blue correction 法の効果の度合いも異なると 考えられる.

本研究においてさまざまな報告との若干の相違の影 響として, フラットベッドスキャナの違いといった測定 環境の影響や EBT2 のロットの違いといったフイルム特 性の変化が示唆できる。したがって EBT2を利用する にあたり，そのロットのフィルム特性を理解し，異なる ロットを利用する場合は特性の変化の有無を確認し, 測定精度の向上につながると認められる場合のみ利用 すべきであると考えられる。 


\section{4. 結 論}

本研究では, EBT2 掞よびEPSON-Seiko 製 10000G を用いて, フラットベッドスキャナが走査垂直方向の線 量の值に影響を及ぼすかを評価した。フラットベッドス キャナによる影響は, 走査垂直方向の光学濃度が不均 一となり，比較的大きな照射野に打いて中央より辺縁に 線量差が 3\%から $8 \%$ 程度大きくなることを示した。 ま た，EDR2より EBT2 は光源による影響が顕著に現れる ことも示した，そのため，EDR2 と同等の測定精度にて 解析を行うには，EBT2 を利用した際にはこの影響を減 少することが必須といえる.

その不均一性の補正を行うために補正関数を求め た，その際に，線量プロファイル自体が非対称であった ことや，EBT とは素材や構成が異なることから，不均 一性の補正関数としては三次式が最も一致した。また， 本研究では EBT2 の特有の雑音の影響を考慮し雑音の 影響を除去して補正式を作成する方法を提案し，検証 を行った，その補正式を利用した結果，走査垂直方向 における不均一性を補正することができ，補正後の測 定值は補正前に比べ基準值に対してより一致する值と なった。 また，この補正係数は，EBT2の感光物質の塗
布ムラの影響を含むため, 同一ロット間で固定の場合， その影響も補正することができ, 線量分布解析の精度 を向上させることができると考えられる.

また，赤色成分拐よび赤色 / 青色成分を用いた際の 測定精度の比較を行った。本研究で作成した走査垂直 方向に扮ける不均一性を補正する方法は，赤色成分扮 よび赤色 / 青色成分の両者に対し同等の効果を示すこ とがわかった，また，線量プロファイルおよび pass ratio を用いて比較した結果，赤色/青色成分の利用によっ て同等もしくは若干の向上を示した.

以上のことから，本研究で作成した走査垂直方向に おける不均一性を補正する方法は，EBT2 に対して有効 であり，線量分布の測定精度が向上寸ることを示した。 また，この補正法は，最初に不均一性の補正のための 関数を求めた後, フィルムロットが変わるまでは同じも のを使うことができる。したがって，補正関数を取得し た後は不均一性の補正法を使わない場合の測定の同様 の流れで測定をすることができるため, さまざまな施設 におけるすべてのフラットベッドスキャナ，EBT2 に対 応が可能であり，臨床に用いるにあたり汎用性に優れる といえる.

\section{参考文献}

1) Spezi E, Angelini AL, Romani F, et al. Characterization of a $2 \mathrm{D}$ ion chamber array for the verification of radiotherapy treatments. Phys Med Biol 2005; 50(14): 3361-3373.

2) Chandraraj V, Stathakis S, Manickam R, et al. Comparison of four commercial devices for RapidArc and sliding window IMRT QA. J Appl Clin Med Phys 2011; 12(2): 338-349.

3) Chandraraj V, Stathakis S, Manickam R, et al. Consistency and reproducibility of the VMAT plan delivery using three independent validation methods. J Appl Clin Med Phys 2011; 12(1): 129-140.

4) Poppe B, Blechschmidt A, Djouguela A, et al. Two-dimensional ionization chamber arrays for IMRT plan verification. Med Phys 2006; 33(4): 1005-1015.

5) Bedford JL, Lee YK, Wai P, et al. Evaluation of the Delta4 phantom for IMRT and VMAT verification. Phys Med Biol 2009; 54(9): N167-N176.

6) Geurts M, Gonzalez J, Serrano-Ojeda P. Longitudinal study using a diode phantom for helical tomotherapy IMRT QA. Med Phys 2009; 36(11): 4977-4983.

7) Sadagopan R, Bencomo JA, Martin RL, et al. Characterization and clinical evaluation of a novel IMRT quality assurance system. J Appl Clin Med Phys 2009; 10(2): 104-119.

8) Feygelman V, Forster K, Opp D, et al. Evaluation of a biplanar diode array dosimeter for quality assurance of step-andshoot IMRT. J Appl Clin Med Phys 2009; 10(4): 64-78.

9) Childress NL, Rosen II. Effect of processing time delay on the dose response of Kodak EDR2 film. Med Phys 2004; 31(8): 2284-2288.

10) Childress NL, Salehpour M, Dong L, et al. Dosimetric accuracy of Kodak EDR2 film for IMRT verifications. Med
Phys 2005; 32(2): 539-548.

11) Shi C, Papanikolaou N, Yan Y, et al. Analysis of the sources of uncertainty for EDR2 film-based IMRT quality assurance. J Appl Clin Med Phys 2006; 7(2): 1-8.

12) Devic S, Seuntjens J, Sham E, et al. Precise radiochromic film dosimetry using a flat-bed document scanner. Med Phys 2005; 32(7): 2245-2253.

13) Andrés $C$, del Castillo $A$, Tortosa $R$, et al. A comprehensive study of the Gafchromic EBT2 radiochromic film. A comparison with EBT. Med Phys 2010; 37(12): 6271-6278.

14) Lindsay $P$, Rink $A$, Ruschin $M$, et al. Investigation of energy dependence of EBT and EBT-2 gafchromic film. Med Phys 2010; 37(2): 571-576.

15) Aldelaijan S, Mohammed H, Tomic N, et al. Radiochromic film dosimetry of HDR ${ }^{192} \mathrm{Ir}$ source radiation fields. Med Phys 2011; 38(11): 6074-6083.

16) Angellier G, Gautier M, Herault J. Radiochromic EBT2 film dosimetry for low-energy protontherapy. Med Phys 2011; 38(11): 6171-6177.

17) Aldelaijan S, Devic S, Mohammed H, et al. Evaluation of EBT-2 model GAFCHROMIC ${ }^{\mathrm{TM}}$ film performance in water. Med Phys 2010; 37(7): 3687-3693.

18) Ong CL, Verbakel WF, Cuijpers JP, et al. Stereotactic radiotherapy for peripheral lung tumors: a comparison of volumetric modulated arc therapy with 3 other delivery tecniques. Radiother Oncol 2010; 97(3): 437-442.

19) Hartmann B, Martisiková M, Jäkel O. Homogeneity of Gafchiromic ${ }^{\circledR}$ EBT2 film. Med Phys 2010; 37(4): 1753-1756.

20) Desroches J, Bouchard H, Lacroix F. Potential errors in optical density measurements due to scanning side in EBT 
and EBT2 Gafchromic film dosimetry. Med Phys 2010; 37(4): 1565-1570.

21) Menegotti L, Delana A, Martignano A. Radiochromic film dosimetry with flatbed scanners: a fast and accurate method for dose calibration and uniformity correction with single film exposure. Med Phys 2008; 35(7): 3078-3085.

22) Sankar A, Ayyangar KM, Nehru RM, et al. Comparison of Kodak EDR2 and Gafchromic EBT film for intensity-modulated radiation therapy dose distribution verification. Med Dosim 2006; 31(4): 273-282.

23) Ju SG, Han Y, Kum O, et al. Comparison of film dosimetry techniques used for quality assurance of intensity modulated radiation therapy. Med Phys 2010; 37(6): 2925-2933.

24) Saur S, Frengen J. GafChromic EBT film dosimetry with flatbed CCD scanner: a novel background correction method and full dose uncertainty analysis. Med Phys 2008; 35(7): 3094-3101.

25) Micke A, Lewis DF, Yu X. Multichannel film dosimetry with nonuniformity correction. Med Phys 2011; 38(5): 2523-2534.
26) CORRECTION PROTOCOL FOR GAFCHROMIC EBT2 DOSIMETRY FILM. INTERNATIONAL SPECIALTY PRODUCTS; 1361 Alps Road, Wayne, New Jersey 07470

27) Kairn T, Aland T, Kenny J. Local heterogeneities in early batches of EBT2 film: a suggested solution. Phys Med Biol 2010; 55(15): L37-L42.

28) Aland T, Kairn T, Kenny J. Evaluation of a Gafchromic EBT2 film dosimetry system for radiotherapy quality assurance. Australas Phys Eng Sci Med 2011; 34(2): 251-260.

29) Low DA, Harms WB, Mutic S, et al. A technique for the quantitative evaluation of dose distributions. Med Phys 1998; 25(5): 656-661.

30）強度変調放射線治療に扮ける物理・技術的ガイドライン 2011. IMRT 物理 QA ガイドライン専門小委員会(日本放射 線腫瘍学会 QA 委員会).

31）橘 英伸, 上原隆三, 松林史泰, 他. 2 次元線量分布測定 器の精度: Matrixx, EDR2, EBT2 の比較. 日本放射線腫 瘍学会第 23 回学術大会抄録集 2010; O-251: 164. 